\title{
Community Relations of the University of Bohol
}

\author{
AMMON DENIS R. TIROL \\ ammondrtirol@universityofbohol.edu.ph \\ ORCID No: 0000-0003-1022-8781
}

\begin{abstract}
Relations with the community of higher educational institutions is a necessary dimension in factoring their institutional sustainability as this fits the generational psyche of both the academe, in their shift from knowledge dispensing to learner-centered, and the students' desire to build social frameworks. The bodies of knowledge relating to community relations, from experiential learning to service learning, supports this necessity for the academe's role of scholarship engagement. A study was made on the perceptions of the university stakeholders on the indicators for institutional sustainability, adapted from the CHED QA tool, on the issues of: relevance of community programs, funding adequacy for the programs, and degree of participation by the school and its constituents. Researcher formulated survey questions were distributed to and answered by key institutional stakeholders: the administrators, faculty members, non-teaching personnel, and students. The sample size for each group of respondents was one-third of their population. The differences in their responses were analyzed through weighted means and group means compared pairwise using the Tukey's honest significance difference (HSD) value. The analysis revealed that the stakeholders were of the same perception that the institutional sustainability attributes on relations with the community for the university were program-relevant, well-funded, and well participated.
\end{abstract}

Keywords: Community relations, Universities, Institutional Sustainability Assessment, Self-Evaluation Document, Service-learning, Weighted Means, Asia, Philippines 


\section{INTRODUCTION}

"For you were called to freedom, brethren; only do not turn your freedom into an opportunity for the flesh, but through love serve one another." - Galatians 5:13

The fifth Key Result Area (KRA) of the Institutional Sustainability Assessment (ISA) framework of the Philippine Commission on Higher Education (CHED) is Relations with the Community or the extra-curricular linkages, service-learning, and outreach of a Higher Educational Institution (HEI). The ISA framework is an Internal Quality Assurance (IQA) tool ${ }^{1}$ to be used by HEls in applying for accreditation provided for in CHED Memorandum Order No. 46 series of 2012 entitled "Policy Standard to Enhance Quality Assurance in Philippine Higher Education through an Outcomes-based and Typed-based Quality Assurance ${ }^{2}$ ". The policy standard for quality assurance envisions that the country's educational systems can match global standards emphasizing the swing from viewing education as transmission of knowledge to creating learnercompetencies. Suitable competencies of the students reflect the changing social values and responsibilities of the times.

The social values of the generation born between 1982 and 2004, or the Millennials, (Raines, 2002) is telling of the technology-driven globally connected society of today. Scholars study the connection of intergenerational personae with social characteristics, and they have identified collective patterns and trends on how each generation think and act in future (Howe \& Strauss, 2007). The Millennials and Generation Z, or those born after 2002, tend to focus on building social frameworks for civic order emphasizing on outcome rather than on money or rhetoric. They are more interested in broad social activities than on individuality (Myers et al., 2010).

1 Institutional Sustainability Assessment Self-Evaluation Document (ISA-SED): An Internal Quality Assurance (IQA) Tool for Philippine Higher Education Institutions. Commonwealth Avenue, Quezon City. http://chedro1.com/wpcontent/uploads/2017/05/Revised-ISA-SED_Final-Version_April-2017.docx (accessed 30 June 2017)

2 CHED Memorandum Order No. 46 Series of 2012 http://www.ched.gov.ph/wpcontent/uploads/2013/07/CMO-No.46-s2012.pdf (accessed 30 June 2017) 
In the past twenty years, the academe has observed an increasing interest of students for meaningful experiential community service. Learning institutions adapted the experiential learning theory of John Dewey (1938) which takes the view learners' experience and not traditional education approach of mere dispensing of knowledge. Bringle et al. (1999) differentiate between volunteerism, community service, and service learning emphasizing on the scholarship of engagement (Boyer, 1996) role of the higher educational institution. The future implication of implementing service learning in the curriculum is counter-effective if imposed in the sense of traditional education mode (Butin, 2017) but advantageous in its proper context (Bender, 2006; Berle, 2006; Cramblit, 2017).

These bodies of knowledge support the need to include the relations with the community as a necessary dimension for the sustainability of higher education. This study intends to determine the Relations with the Community of the University of Bohol to aid in formulating institutional policies and program interventions. Specifically, this study aims to answer the following questions:

- How do the institutional stakeholders assess the relations with community of UB regarding: Relevance of the Programs, Adequacy of Funding, and Degree of Participation?

- Are there significant differences in the assessment of the administrators, faculty, non-teaching personnel and students on the assessment of the relations with community of UB?

The responsiveness of the institution to needs of the community through its extension programs indicates a heightened sense of social responsibility among its stakeholders. Lazarus (2001) highlighted the lack of capacity in many educational institutions to integrate community service into mainstream academic programs which is a vehicle for, and measure of, civic engagement in higher education. The government and higher education need to agree on the concept of "responsiveness" as this ambiguity contributed to the virtual marginalization of its social dimension. Policy goals for social and economic development should relate to the goals of higher education.

Boyer (1996) proposed a conceptual framework referred to as scholarship of engagement to expand the service dimension of scholarly 
activities with four forms: scholarship of discovery, scholarship of integration, scholarship of application, and scholarship of teaching. Although he proposed it as an enhancement of capabilities of the faculty, it necessarily meant the improvement of the educational institution.

Byrne (2016) said that engagements or outreaches would be the defining characteristics of the University of the Future. The educational institution must emphasize the creation of partnerships and interconnection with elements of society. The notion of "engagement" goes beyond traditional extension and outreach by requiring a sharing of knowledge and resources to serve society more effectively.

The educational institution as a corporate citizen is bound to a psychological contract with the community. This principle was expounded by Burke (1999) when he forwarded the Principle of Neighbor of Choice as a strategy for corporate survival by shaping the contact with stakeholders in the community. Community involvement is considered a competitive edge.

\section{Methodology}

Data were obtained through a researcher-developed questionnaire distributed to different groups of respondents in the University of Bohol.

Table 1. University of Bohol Respondents

\begin{tabular}{|l|c|c|}
\hline Respondent group & Population & Sample Size \\
\hline Administrative officers & 44 & 15 \\
\hline Faculty & 300 & 101 \\
\hline Staff & 100 & 34 \\
\hline Students & 343 & 115 \\
\hline Total & 787 & 265 \\
\hline
\end{tabular}

The population for the administrative officers is the total for the 10 members of the University Board and the 34 officers-in-charge of responsibility centers. The faculty members were all full-time tenured faculty members of the 19 academic departments. The student respondents were drawn from the graduating class of the different colleges. From the ranks of all office personnel who have been employed at the school for more than 3 years were randomly selected, 34 respondents. The sample size for the respondents was one-third from each group. 
The first step in selecting the respondents was to list in alphabetical order all members of each group. Then a random number was generated from Microsoft Excel the times according to the group's sample size, e.g. 34 random numbers for the staff group. A test group of 64 respondents, or one-fourth of the actual sample size, was also determined following the same steps.

The researcher-made questionnaire of 10 -items was fine-tuned on the test group before distributed to the respondents. The questions designed to assess the university's relations with the community were categorized into: Program relevance (4 items), Funding adequacy (3 items), and Degree of participation (3 items). These questions were adopted from the Commission on Higher Education Institutional Sustainability Assessment (ISA) framework indicators on Relations with the Community, Networking and Linkages, and Extension Programs.

The weighted means of the groups' responses were computed after their assessments were rated according to the following values:

\begin{tabular}{|l|l|c|}
\hline $\begin{array}{l}\text { Degree of } \\
\text { Relevance }\end{array}$ & $\begin{array}{l}\text { Respondent's assessment of UB's } \\
\text { Provisions/Services/Conditions on Relations } \\
\text { with the Community }\end{array}$ & $\begin{array}{c}\text { Mean } \\
\text { Weight } \\
\text { Equivalent }\end{array}$ \\
\hline Very Relevant & $\begin{array}{l}\text { Perfectly suited or answers the felt needs of } \\
\text { the community }\end{array}$ & 4 \\
\hline Relevant & $\begin{array}{l}\text { Almost, but not totally, attune to felt needs } \\
\text { of the community }\end{array}$ & 3 \\
\hline Fairly Relevant & $\begin{array}{l}\text { Hardly answers the felt needs of the } \\
\text { community }\end{array}$ & 2 \\
\hline Irrelevant & $\begin{array}{l}\text { Does not address the felt needs of the } \\
\text { community }\end{array}$ & 1 \\
\hline
\end{tabular}

\section{Results and Discussion}

The institutional social responsibility as actually enunciated and applied through its community programs is indicative of the degree of the social responsibility of its stakeholders. The studies of Lazarus (2001) and Byrne (2000) have made known the importance of addressing the social dimension as the new defining consideration for the educational institutions in the future. Lazarus saw the connection of policy goals for social and economic development and the goals for education. Byrne said that the "University of the Future" is defined by the existence and broadness of its relations with the different sectors of society. Burke (1999) expounded the Principle of Neighbor of Choice as a strategy of corporate 
survival by shaping the contact with the stakeholders in the community. The educational institution as a corporate citizen is bound to a psychological contract with the community.

The assessment of the relevance of community programs by the respondents is summarized in Table 2.

Table 2. Relevance of UB Community Programs

\begin{tabular}{|c|c|c|c|c|c|c|c|c|c|c|}
\hline \multirow{2}{*}{ Items } & \multicolumn{2}{|c|}{ Admin } & \multicolumn{2}{|c|}{ Faculty } & \multicolumn{2}{|c|}{ Staff } & \multicolumn{2}{|c|}{ Students } & \multicolumn{2}{|c|}{ Total } \\
\hline & $\bar{x}$ & I & $\bar{x}$ & 1 & $\bar{x}$ & I & $\bar{x}$ & I & $\bar{x}$ & I \\
\hline $\begin{array}{l}\text { 1. UB has academic } \\
\text { and non-academic } \\
\text { programs that contribute } \\
\text { to the achievement } \\
\text { of local/ regional/ } \\
\text { national priorities (e.g., } \\
\text { poverty alleviation, } \\
\text { environmental } \\
\text { management, health) }\end{array}$ & 3.17 & $\mathrm{R}$ & 3.20 & $\mathrm{R}$ & 3.26 & $\mathrm{R}$ & 3.02 & $\mathrm{R}$ & 3.16 & $\mathrm{R}$ \\
\hline $\begin{array}{l}\text { 2. UB has partnerships/ } \\
\text { arrangements that } \\
\text { promote dialogue } \\
\text { with professional, } \\
\text { organizations, } \\
\text { industry, and other } \\
\text { external groups, } \\
\text { such as government } \\
\text { and non-government } \\
\text { organizations, socio- } \\
\text { civic and religious } \\
\text { groups. }\end{array}$ & 3.17 & $\mathrm{R}$ & 3.11 & $\mathrm{R}$ & 3.29 & VR & 2.96 & $\mathrm{R}$ & 3.13 & $\mathrm{R}$ \\
\hline $\begin{array}{l}\text { 3. UB responds to } \\
\text { changing patterns } \\
\text { and requirements of } \\
\text { employment as well } \\
\text { as to the needs of the } \\
\text { community. }\end{array}$ & 3.33 & VR & 3.12 & $\mathrm{R}$ & 3.19 & $\mathrm{R}$ & 2.84 & $\mathrm{R}$ & 3.12 & $\mathrm{R}$ \\
\hline $\begin{array}{l}\text { 4. UB integrates its } \\
\text { extension program with } \\
\text { research and instruction. } \\
\text { Lessons from extension } \\
\text { programs are used to } \\
\text { inform the design of } \\
\text { research projects and } \\
\text { the content of related } \\
\text { mainstream academic } \\
\text { programs. }\end{array}$ & 3.11 & $\mathrm{R}$ & 3.06 & $\mathrm{R}$ & 3.12 & $\mathrm{R}$ & 2.90 & $\mathrm{R}$ & 3.05 & $\mathrm{R}$ \\
\hline Group Mean & 3.19 & $\mathrm{R}$ & 3.12 & $\mathrm{R}$ & 3.21 & $\mathrm{R}$ & 2.93 & $\mathrm{R}$ & 3.12 & $\mathrm{R}$ \\
\hline
\end{tabular}


Legend: VR Very relevant $3.25 \quad-4.00$

$\begin{array}{llll}\text { R } & \text { Relevant } & 2.50 & -3.24 \\ \text { FR } & \text { Fairly relevant } & 1.75 & -2.49 \\ \text { NR } & \text { Not relevant } & 1.00 & -1.74\end{array}$

The grand mean of the ratings by the respondents of 3.12 indicate they found the community programs relevant.

The item with the highest mean 3.16 is on the contribution of UB academic and non-academic programs towards the achievement of established government priorities. This item has been given highly contrasting rankings by the administrators as their highest and the students as their lowest which should be made an area of concern that should be resolved.

The item with the lowest mean 3.05 is the integration of lessons from extension program into the design of research projects and the content of related mainstream academic programs. This item is consistently ranked the lowest mean by the administrators, faculty, and staff. The students ranked this item their second lowest. The observation that there is a need to convert lessons learned from the community programs into mainstream educational goals is also the observation presented by Lazarus (2001) in his study of educational institutions regarding community outreach programs. The student respondents gave the lowest group mean 2.93 as they perceive less intense social engagement (Byrne, 2016) in their college experience.

The second category of questions is meant to assess the adequacy of funding for community programs which hints at the degree of support as shown by established partnerships, criteria and monitoring schemes, and support mechanisms in UB. The assessment of funding adequacy of community programs by the respondents is summarized in Table 3. 
Table 3. Funding Adequacy of Community Programs

\begin{tabular}{|c|c|c|c|c|c|c|c|c|c|c|}
\hline \multirow{2}{*}{ Items } & \multicolumn{2}{|c|}{ Admin } & \multicolumn{2}{|c|}{ Faculty } & \multicolumn{2}{|c|}{ Staff } & \multicolumn{2}{|c|}{ Students } & \multicolumn{2}{|c|}{ Total } \\
\hline & $\overline{\boldsymbol{x}}$ & I & $\overline{\boldsymbol{x}}$ & 1 & $\overline{\boldsymbol{x}}$ & 1 & $\overline{\boldsymbol{x}}$ & I & $\overline{\boldsymbol{x}}$ & I \\
\hline $\begin{array}{l}\text { 1. UB has partner } \\
\text { institutional } \\
\text { organizations } \\
\text { and consortium } \\
\text { arrangements, which } \\
\text { contribute resources } \\
\text { and information for its } \\
\text { programs. }\end{array}$ & 2.72 & $\mathrm{R}$ & 2.84 & $\mathrm{R}$ & 3.05 & $\mathrm{R}$ & 2.91 & $\mathrm{R}$ & 2.88 & $\mathrm{R}$ \\
\hline $\begin{array}{l}\text { 2. Community programs } \\
\text { are evaluated and } \\
\text { monitored for cost- } \\
\text { benefit efficiency. }\end{array}$ & 2.89 & $\mathrm{R}$ & 2.85 & $\mathrm{R}$ & 3.17 & $\mathrm{R}$ & 2.79 & $\mathrm{R}$ & 2.92 & $\mathrm{R}$ \\
\hline $\begin{array}{l}\text { 3. UB provides support } \\
\text { mechanisms for its } \\
\text { extension programs. }\end{array}$ & 3.22 & $\mathrm{R}$ & 2.98 & $\mathrm{R}$ & 3.29 & VR & 2.88 & $\mathrm{R}$ & 3.09 & $\mathrm{R}$ \\
\hline Group Mean & 2.94 & $\mathrm{R}$ & 2.89 & $\mathrm{R}$ & 3.17 & $\mathrm{R}$ & 2.86 & $\mathrm{R}$ & 2.97 & $\mathrm{R}$ \\
\hline
\end{tabular}

The grand mean of the ratings by the respondents on the funding adequacy of community programs is 2.97 which indicates that the funding is adequate.

The item with the highest mean 3.09 is UB's support mechanisms for its extension programs. This item is consistently ranked highest by the administrators, faculty, and staff. They are aware of the established administrative policies regarding support for community programs.

The item with the lowest mean 2.88 is on UB's partnering with organizations and consortia to generate resources and information for its community extension programs. This item is consistently ranked lowest by the administrators, faculty, and staff indicating the common observation shared by these respondent groups. It should be noted that the student respondents do not share this common observation indicating a gap in the sharing of information regarding the adequacy of funding community programs.

The set of questions to measure the degree of community participation of UB as an institution through its contributions, of the faculty and students through the course offerings, and of the community itself through its feedback on UB's community programs are presented in Table 4.

The group mean of the ratings by all respondents on the degree of participation of UB community programs is 3.11 which indicates that the 
community programs have adequately participated. The staff respondents gave the highest group mean of 3.28 with a Very Relevant rating. The item on integrating community extension into a course offering to allow participation of faculty and students were also rated Very Relevant by administrators and staff.

Table 4. Degree of Participation in UB Community Programs

\begin{tabular}{|c|c|c|c|c|c|c|c|c|c|c|}
\hline \multirow{2}{*}{ Items } & \multicolumn{2}{|c|}{ Admin } & \multicolumn{2}{|c|}{ Faculty } & \multicolumn{2}{|c|}{ Staff } & \multicolumn{2}{|c|}{ Students } & \multicolumn{2}{|c|}{ Total } \\
\hline & $\bar{x}$ & I & $\bar{x}$ & 1 & $\bar{x}$ & I & $\bar{x}$ & 1 & $\bar{x}$ & I \\
\hline $\begin{array}{l}\text { 8. UB contributes to } \\
\text { local/ regional/ national } \\
\text { development through its } \\
\text { extension programs. }\end{array}$ & 3.17 & $\mathrm{R}$ & 3.01 & $\mathrm{R}$ & 3.24 & $\mathrm{R}$ & 2.92 & $\mathrm{R}$ & 3.08 & $\mathrm{R}$ \\
\hline $\begin{array}{l}\text { 9. Community extension } \\
\text { programs are integrated } \\
\text { in course offerings to } \\
\text { enable participation of } \\
\text { faculty and student. }\end{array}$ & 3.28 & VR & 3.05 & $\mathrm{R}$ & 3.36 & VR & 2.99 & $\mathrm{R}$ & 3.17 & $\mathrm{R}$ \\
\hline $\begin{array}{l}\text { 10. Feedback of the } \\
\text { community is integral } \\
\text { in formulating } \\
\text { and implementing } \\
\text { community programs. }\end{array}$ & 3.11 & $\mathrm{R}$ & 3.00 & $\mathrm{R}$ & 3.24 & $\mathrm{R}$ & 2.94 & $\mathrm{R}$ & 3.07 & $\mathrm{R}$ \\
\hline Group Mean & 3.19 & $\mathrm{R}$ & 3.02 & $\mathrm{R}$ & 3.28 & VR & 2.95 & $\mathrm{R}$ & 3.11 & $R$ \\
\hline
\end{tabular}

The grand mean of the ratings by the respondents on the degree of participation in community programs is 3.11 which indicate that the practice is adequate.

The item with the highest mean rating 3.17 is the aspect of integrating extension programs in the course offerings to enable participation of faculty and students consistent with the perception held by all the other respondent groups on the aspects of the degree of participation. This ranking is consistent with all respondent groups.

Item 3 or "feedback of the community is integral in formulating and implementing community programs" has the lowest mean of 3.07. The administrator, faculty, and staff respondent groups similarly ranked this item their lowest. The student respondents ranked lowest a different item indicating a differing perception towards community feedback in community programs. Among the respondents, the staff has the highest composite mean, and the students have the lowest. 
The test of variances for all the responses taken revealed that there is a significant difference in their perception that Relations with the Community in UB is adequate. This difference is revealed in the analyses of group means compared pairwise using the Tukey's HSD value as presented in Table 5.

Table 5. Multiple Comparison of Group Means for Relations with the Community using the Tukey Method

\begin{tabular}{|l|c|c|c|c|}
\hline \multicolumn{1}{|c|}{ Pair } & $\overline{\boldsymbol{x}}$ & Result & HSD at 0.05 & Interpretation \\
\hline Admin \& Faculty & $\mathbf{0 . 1 0}$ & $<$ & & Not Significant \\
\hline Admin \& Staff & $\mathbf{0 . 1 1}$ & $<$ & & Not Significant \\
\hline Admin \& Students & $\mathbf{0 . 2 0}$ & $<$ & \multirow{4}{*}{$\mathbf{0 . 2 5 9 7 8 9 6 1}$} & Not Significant \\
\cline { 1 - 2 } Faculty \& Staff & $\mathbf{0 . 2 1}$ & $<$ & & Not Significant \\
\hline Faculty \& Students & $\mathbf{0 . 1 0}$ & $<$ & & Not Significant \\
\hline Staff \& Students & $\mathbf{0 . 3 1}$ & $>$ & & Significant \\
\cline { 1 - 2 } & & &
\end{tabular}

The five pairing of group means indicates that the mean differences are below 0.25978961 except for the pair between the staff and student with a difference of 0.31 indicating that the perception of the student and staff respondents regarding the community programs of UB are significantly different. The dispersion of means of the students and staff exceeded the allowable value for the distribution at $95 \%$ probability for this size of samples and variables.

\section{Summary of Findings}

The institutional indicators of UB's relationship with community were assessed by the relevance of community programs, their funding adequacy, and degree of involvement by stakeholders in these programs. Statistical treatment on the survey responses for Relations with the Community revealed a highly contrasting profile of responses between the staff and student respondents. On all the items, highest ratings were given by the staff while the students gave the lowest ratings. The students gave a contrasting perception on Relations with the Community compared with the other respondent groups. A significant difference was revealed by the analysis of variance on the group responses and specifically traced after pairwise comparison to the highly contrasting response of the staff and student respondents.

The relevance of UB community programs was indicated by the perceived contribution of UB programs towards the achievement 
of government priorities, linkage with other institutional partners, responsiveness to community needs, and integration of extension program with research and instruction. Respondents' rating for this aspect of the relationship with the community was 3.12 or relevant. The item on UB's contribution towards the achievement of government priorities had the highest mean (3.16) while the integration of extension program with research and instruction had the lowest mean (3.05).

Funding adequacy of community programs was determined by the existence of contributing institutional partner, monitoring and evaluation for cost-benefit, and support mechanism for extension programs. Respondents mean rating was 2.97 or relevant with support mechanism given the highest (3.09) and the existence of contributing institutional partners the lowest at 2.88 .

The degree of participation in community programs was taken as the involvement of UB as an institution, the faculty and students, and the community in community programs. Overall rating by the respondents on participation was 3.11 with the participation of faculty and students the highest (3.17) and participation of the community the lowest (3.07).

\section{Conclusion}

The findings of the study indicate that the relations with the community of the University of Bohol were program-relevant, well-funded, and well participated.

\section{Implications}

The research items rated less than relevant will be improved through appropriate policy and program interventions to make the university's relations with the community more responsive to its stakeholders.

\section{LITERATURE CITED}

Bender, C. J. G., Daniels, P., Lazarus, J., Naude, L., \& Sattar, K. (2006). Service-learning in the Curriculum: A Resource for Higher Education. CHE (Council for Higher Education).

Berle, D. (2006). Incremental integration: A Successful Service-Learning Strategy. International Journal of Teaching and Learning in Higher 
Education, 18(1), 43-48. http://www.isetl.org/ijtlhe/pdf/IJTLHE65.pdf (accessed on 30 June 2017)

Boyer, E. L. (1996). The scholarship of engagement. Bulletin of the American Academy of Arts and Sciences, 49(7), 18-33.

Bringle, R. G., Games, R., \& Malloy, E. A. (1999). Colleges and universities as citizens. Allyn and Bacon, 160 Gould Street, Needham Heights, MA 02494-2315.

Burke, Edmund M. (1999). Corporate Relations with the Community. Greenwood Publishing Group.

Butin, D. (2010). Service-learning in Theory and Practice: The Future of Community Engagement in Higher Education. Springer.

Byrne, J. V. (2000). Engagement: a defining Characteristic of the University of Tomorrow. Journal of Higher Education Outreach and Engagement, 6(1), 13-21.

Byrne, J. V. (2016). Outreach, Engagement, and the Changing Culture of the University. Journal of Higher Education Outreach and Engagement, 20(1), 53-58.

Cramblit, M. M. (2017). Hopeful Engagement: The Sentimental Education of University-Sponsored Service Learning. In Anthropological Perspectives on Student Futures (pp. 133-156). Palgrave Macmillan US.

Cuyegkeng, M., Teehanke, B., Detoya, G., \& Tablante, D. (2017, January 24). Institutional Sustainability Assessment Self-Evaluation Document (ISA-SED): An Internal Quality Assurance (IQA) Tool for Philippine Higher Education Institutions. Commonwealth Avenue, Quezon City. http://chedro1.com/wp-content/uploads/2017/05/Revised-ISA-SED_ Final-Version_April-2017.docx (accessed on 30 June 2017) 
Dewey, J. (1938). Experience and Education New York. Touchstone, 18.

Howe, N., \& Strauss, W. (2007). The next 20 years. Harvard Business Review, 85, 41-52.

Lazarus, J. (2001). A New Contract between Higher Education and Society: Responsiveness through a Scholarship of Engagement. In third Consultative Conference of the Council on Higher Education held on November 2001 (Vol. 29).

Myers, K. K., \& Sadaghiani, K. (2010). Millennials in the workplace: A communication perspective on Millennials' organizational relationships and performance. Journal of Business and Psychology, 25(2), 225238.

Philippines, Commission on Higher Education, Office of the President. (2012). Memorandum Order no. 46 series of 2012. Quezon City.http:// www.ched.gov.ph/wp-content/uploads/2013/07/CMO-No.46-s2012. pdf (accessed on 30 June 2017)

Raines, C. (2002). Managing Millennials. Connecting Generations: The Sourcebook, 16. 